\title{
Cyperus esculentus L. as a biotechnological raw material and substitute for peanuts in the production of confectionery products
}

\author{
$N V$ Kiyashko $^{1}, S A$ Berseneva $^{1}, G A$ Belova $^{1}$, and $A N$ Belov $^{2, *}$ \\ ${ }^{1}$ Primorsky State Agricultural Academy, 44 Blucher Ave., Ussuriysk, 692500, Primorsky Krai, \\ Russian Federation, \\ ${ }^{2}$ Far Eastern Federal University, Russky Island, Ajax Bay. 10, Vladivostok 690922, Russian \\ Federation
}

\begin{abstract}
A comparative chemical composition of peanuts and Cyperus esculentus - a raw material that does not contain gluten, rich in fat, vitamins and minerals, is given. The possibility of replacing crushed peanuts with alternative raw materials - Cyperus esculentus. nodules is considered. Appropriate preparation of raw materials is offered. Sprinkling shortcake dough with crushed Cyperus esculentus . nodules, pre-soaked for 12 hours in water, fried and crushed will increase the nutritional value of the product.
\end{abstract}

\section{Introduction}

Since time immemorial, biotechnology has been used mainly in the food and textile industry, namely, in winemaking, baking, fermentation of dairy products, processing of flax, leather, etc., i.e. in processes based on the use of microorganisms. In recent decades, the possibilities of biotechnology have expanded enormously. Today, the objects of biotechnology are viruses, bacteria, protista, yeast, as well as plants, animals, or isolated cells and subcellular structures (organelles) [1].

The modern food industry, as a branch of biotechnology, is engaged in the study and development of the theory and practice of creating food products for general, therapeutic and preventive purposes and special orientation. This is the industry of food ingredients auxiliary technological additives introduced into food products during their manufacture to increase their useful properties [2].

A huge number of food ingredients are currently imported, and therefore, the organization of their production in Russia is an urgent, socially demanded task. One of these natural food ingredients of functional significance is the Cyperus esculentus, - a representative of the Cyperaceae Juss.

The genus Cyperus L. in the world flora is represented by 300 species distributed in tropical, subtropical and less often - temperate regions of the planet. There are only 14

\footnotetext{
*Corresponding author: belov.an@,dvfu.ru
} 
species in Russia, and 5 species grow in the Far East: Cyperus glomeratus L., C. difformis L., C. fuscus L., C. orthostachyus Franch.et Savat., C. Amuricus Maxim. [3]

Cyperus esculentus does not grow in the Far East, it is typical for regions of the Northern hemisphere with a climate from moderate to subtropical. It is considered to be native to the Mediterranean and North Africa.

The crop is not widespread, although it has a high nutritional value and a pleasant taste. In Russia, Cyperus esculentus has been known since the end of the XVIII century under the names "zimovnik" and "syt", currently it is more often called "chufa", ground almonds or tiger nuts.

Cyperus esculentus - is a perennial herb, representative of the Cyperaceae Juss, cultivated as a food plant because of the edible nodules on the roots [4] (fig. 1).

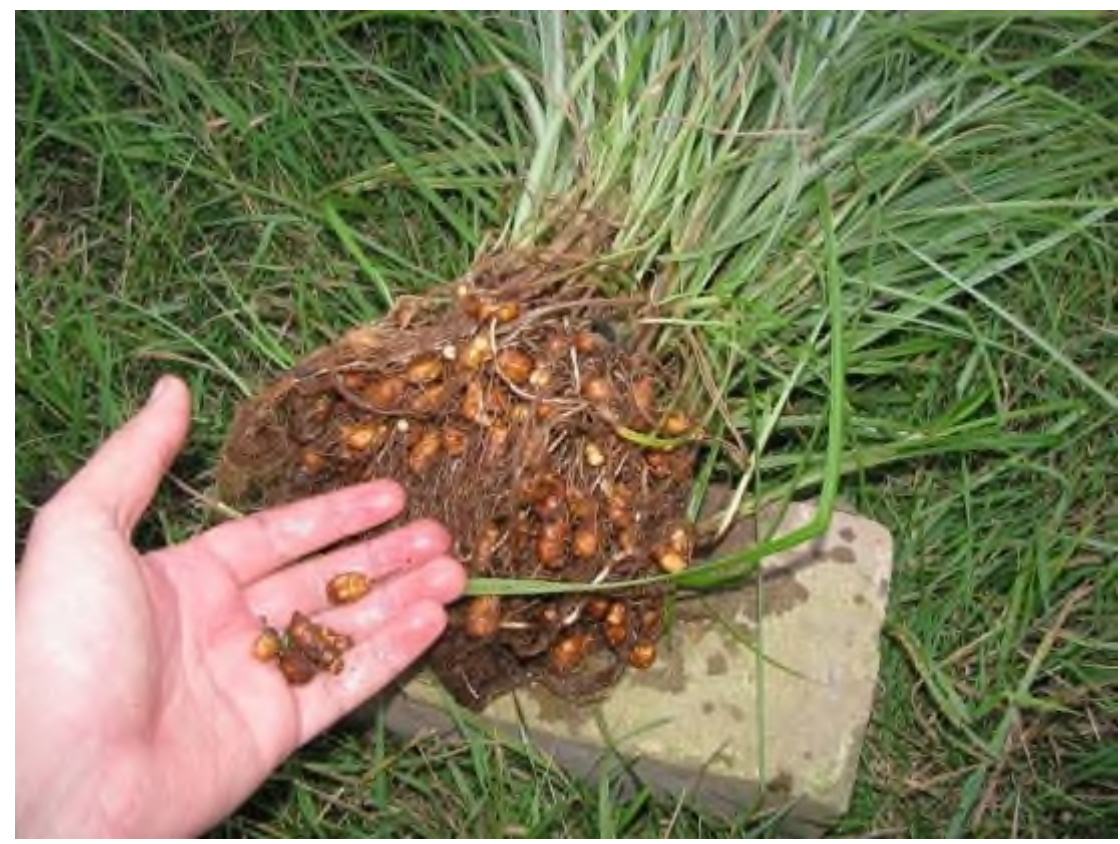

Fig. 1. Morphology of Cyperus esculentus L.

Cyperus esculentus - is one of the first plants cultivated by man: vessels with nodules were discovered by archaeologists in the tombs of Egyptian pharaohs. Tiger nuts were used by the ancient Egyptians for medical purposes: cleaning the mouth, enema, ophthalmology, ointment for dressing wounds, as well as incense for fumigating homes and clothing along with myrrh incense [5-6].

From Egypt, Arab merchants spread the tiger nut to the North and West of Africa, Sicily, and Spain. Tiger nuts are known in other parts of the world, especially in the region of Valencia (Spain) [7-8].

In recent years, innovative enterprises that are engaged in both growing and processing exclusive plants to produce biologically valuable products, in particular, LLC "Russian Oliva" (Voronezh), have shown an active practical interest in ground almonds in Russia [9].

Cyperus esculentus nodules contain up to $28 \%$ of fatty oil, $15-20 \%$ of sugars, $20-25 \%$ of starchy substances, about $2 \%$ of crude protein, and other substances [10].

Doctors recommend using Cyperus esculentus nodules for people with diabetes. Milk from ground Cyperus esculentus contributes to the treatment of gastrointestinal diseases. 
Cyperus esculentus helps to purify the body and removes radionuclides from it. The taste and smell of the nodules of this plant resemble almonds. Flour from Cyperus esculentus nodules is added to the dough when baking cupcakes, cookies, bread and marzipan products. To make gluten-free bread, it is possible to combine chickpea, amaranth flour and flour from Cyperus esculentus nodules [11-14]. Good indicators were obtained when adding the product of processing Cyperus esculentus to bakery products in the amount of 3 , 4 and 5\% of the amount of wheat flour of the highest grade in the recipe [15]. Research conducted at the Moscow State University of Food Production has proved that adding 5\% of tiger nuts instead of raw meat is effective [16]. A draft of technical specifications for "Aromatniy" pate and semi-finished products stuffed and chilled from poultry meat with the introduction of processed Cyperus esculentus products has been developed [17].

The purpose of the research - is to evaluate the possibility and method of using nodules of Cyperus esculentus grown in the agro-ecological conditions of the Primorsky Krai as a substitute for peanuts in the production of confectionery products (sprinkling cakes made from shortbread dough).

\section{Materials and methods}

The research was conducted in the bakery department of the student nutrition combine of the Federal State Budgetary Educational Institution of Higher Education "Primorskaya State Agricultural Academy" (hereinafter referred to as the - FSBEI HE Primorskaya SAA).

To conduct a comparative analysis of the quality and nutritional value of Cyperus esculentus and peanuts, we baked rings-shortbread cakes according to a standard recipe. The recipe includes flour of the highest grade, margarine, eggs, sugar, peanuts. All raw materials meet the requirements of standards and specifications.

The order of research included the following stages: 1) development of an optimal method for preparing raw material, 2) establishment of raw material quality indicators, 3) baking cakes, and their organoleptic assessment, 4) calculation of energy value, fat content, protein and carbohydrates of finished products.

To conduct research, we took Cyperus esculentus nodules obtained as a result of cultivation on the collection site of the Academy within the framework of the final qualifying work.

Cyperus esculentus was sorted, cleaned of impurities, unnecessary nodules and earth, and then washed. Cyperus esculentus nodules had a pleasant taste and smell, characteristic of this species, without extraneous smell and/or bitter taste, without mustiness and rancidity. Nodules were crushed and ground in a laboratory mill.

To study Cyperus esculentus as a nut substitute, the following processing options were investigated:

1. Nut of peanut crushed, peeled, fried - control.

2. Cyperus esculentus nodules are not fried, ground into a powder.

3. Cyperus esculentus nodules are fried, soaked for 4 hours, ground into a powder.

4. Cyperus esculentus nodules are fried, soaked for 4 hours, crushed.

5. Cyperus esculentus nodules are fried, soaked for 8 hours, ground into a powder.

6. Cyperus esculentus nodules are fried, soaked for 8 hours, crushed.

7. Cyperus esculentus nodules are fried, soaked for 12 hours, ground into a powder.

8. Cyperus esculentus nodules are fried, soaked for 12 hours, crushed.

Based on the results of the organoleptic evaluation of the experimental samples, the optimal method of using Cyperus esculentus as a sprinkling shortbread cakes was determined. 


\section{Results and discussion}

As a result of research, it was found that peanuts have a yellow color with brownish inclusions after frying, the taste of peanuts is sweet, nutty, characteristic of peanuts.

Fresh Cyperus esculentus nodules have a very firm consistency, so they need to be soaked for a softer consistency. The taste of the nodules of fresh Cyperus esculentus is sweet, resemble almonds. After 4, 8 and 12 hours of soaking and frying the nodules, the taste changes and resembles coffee, the color is different - from brown, with inclusions of white pulp to dark brown, with inclusions of brownish pulp (table 1).

Table 1. Organoleptic evaluation of peanuts and Cyperus esculentus after processing.

\begin{tabular}{|c|c|c|c|}
\hline Variant & Color & Smell & Taste \\
\hline $\begin{array}{c}\text { Nut of peanut crushed, } \\
\text { peeled, fried }\end{array}$ & brown & $\begin{array}{c}\text { specific, } \\
\text { characteristic of } \\
\text { peanuts }\end{array}$ & $\begin{array}{c}\text { sweet, characteristic of } \\
\text { peanuts }\end{array}$ \\
\hline $\begin{array}{c}\text { Cyperus esculentus } \\
\text { nodules are not fried, } \\
\text { ground into a powder. }\end{array}$ & brown & walnut & sweetish \\
\hline $\begin{array}{c}\text { Cyperus esculentus } \\
\text { nodules are fried, } \\
\text { soaked for 4 hours, } \\
\text { ground into a powder. }\end{array}$ & $\begin{array}{c}\text { brown with } \\
\text { inclusions of white } \\
\text { pulp }\end{array}$ & $\begin{array}{c}\text { with a hint of coffee, } \\
\text { pronounced strongly }\end{array}$ & $\begin{array}{c}\text { sweet, with a hint of } \\
\text { coffee }\end{array}$ \\
\hline $\begin{array}{c}\text { Cyperus esculentus } \\
\text { nodules are fried, } \\
\text { soaked for 4 hours, } \\
\text { crushed. }\end{array}$ & $\begin{array}{c}\text { brown, uneven } \\
\text { with a hint of coffee, } \\
\text { pronounced strongly }\end{array}$ & sweet, with a hint of \\
coffee
\end{tabular}

Peanuts, because of high fat content, are not crushed into powder, it can only be split into pieces. Cyperus esculentus L., due to its lower fat content, crumbles well into powder and can be added to flour, you can sprinkle it on top of confectionery, and unlike peanuts, it does not cause allergies.

Cyperus esculentus nodules contain almost 2 times more nitrogen-free extractives than peanuts. The nodules contain - fiber, a lot of vitamins and amino acids. A comparative analysis of raw material is presented in table 2 . 
Table 2. Chemical composition of peanuts and Cyperus esculentus L.

\begin{tabular}{|c|c|c|}
\hline chemical composition & Peanuts & Cyperus esculentus L \\
\hline Fats, \% & 42.0 & 21.8 \\
\hline Protein, \% & 26.6 & 7.1 \\
\hline Water, \% & 7.9 & 9.5 \\
\hline Nitrogen-free extractives, \% & 17.7 & 49.9 \\
\hline Fiber, \% & 8.1 & 17.0 \\
\hline
\end{tabular}

From all the proposed variants of the experiment, it was found that Cyperus esculentus nodules soaked for 8 hours, fried, ground into powder and Cyperus esculentus nodules soaked for 12 hours, fried and crushed into pieces have the best organoleptic characteristics. These options were used for sprinkling cakes.

As a result, it was determined that the appearance of the cakes, when sprinkled with crushed Cyperus esculentus nodules, is better than ground, and the loss of sprinkling is less (figure 2). It is better to add ground Cyperus esculentus nodules to the dough, and use crushed Cyperus esculentus as a sprinkle.

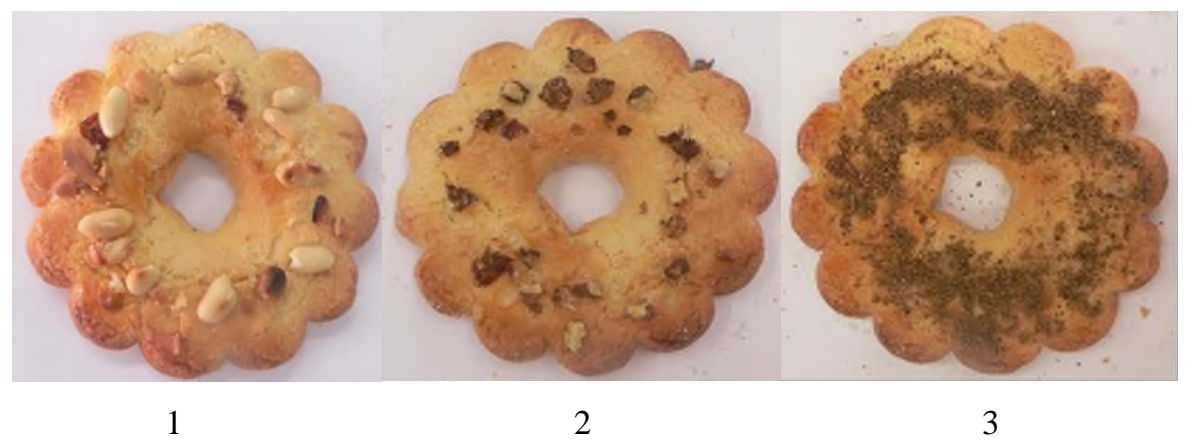

Fig. 2. The appearance of the cakes of dough: 1) cakes sprinkled with peanuts; 2) cakes sprinkled with fried and crushed Cyperus esculentus nodules; 3 ) cakes, sprinkled with fried and ground Cyperus esculentus nodules.

Calculation of the energy value of a sprinkle of peanuts and Cyperus esculentus showed that the caloric content of Cyperus esculentus nodules is 1.8 times lower than the caloric content of peanuts and amounts to $293 \mathrm{kcal}$ or $1223 \mathrm{~kJ}$ (table 3).

Table 3. Calculation of the energy value of peanuts and Cyperus esculentus L.

\begin{tabular}{|c|c|c|c|c|}
\hline Name of product & \multicolumn{3}{|c|}{ Content, g } & Energy value, $\mathrm{kcal} / \mathrm{kJ}$ \\
\hline & protein & fats & $\begin{array}{c}\text { carbohydrat } \\
\text { es }\end{array}$ & \\
\hline Peanuts & 26.6 & 42.0 & 8.1 & $517 / 2160$ \\
\hline Cyperus esculentus L. & 7.1 & 21.8 & 17.0 & $293 / 1223$ \\
\hline
\end{tabular}

The reduction in caloric content is mainly due to the lower fat content in Cyperus esculentus nodules $-21.8 \mathrm{~g} / 100 \mathrm{~g}$ of the product, while its content in peanuts is $42.0 \mathrm{~g} / 100 \mathrm{~g}$ of the product. 


\section{Conclusion}

This paper presents a scientific and theoretical justification for the prospects of using Cyperus esculentus as a biotechnological raw material and nut substitute in the food and confectionery industry and the introduction and cultivation of Cyperus esculentus in the Far East, including the Primorsky Krai.

The features of geographical location of the Primorsky Krai and its agro-climatic resources make it possible to grow Cyperus esculentus on a production scale, since in the wild flora representatives of this genus favorably tolerate the specific monsoon climate of the region under study.

In comparison with peanuts, Cyperus esculentus nodules contain less fat $-21.8 \mathrm{~g} / 100$, protein $-7.1 \mathrm{~g} / 100$ and more nitrogen - free extractives $-49.9 \%$. Unlike peanuts, Cyperus esculentus protein does not cause allergies. To sprinkle products made from shortbread dough, it is recommended to soak the Cyperus esculentus nodules for 8 or 12 hours, fry and crush.

Also, the introduction of Cyperus esculentus is a biotechnological raw material in the food industry.

\section{References}

1. Annenkov N I 1878 Cyperus esculentus Botanical dictionary XXI (SPb.: Publishing house Imperial Academy of Sciences) p 645

2. 1890-1907 Ground almonds Encyclopedia of Brockhaus and Efron: in 86 volumes (82 volumes and 4 additional) vol XII (23) ( $\mathrm{SPb}$ ) p 495

3. Shishkin B K 1935 Cyperus Flora of the USSR: in 30 volume ed of volume B K Shishkin main ed V L Komarov vol 3 (Leningrad: Publishing house of the USSR Academy of Sciences) pp 21-22 p 636

4. Rakov N S, Saksonov S V 2007 Cultivated plants of the Ulyanovsk region Phytodiversity of Eastern Europe № 4 64-108

5. Golitsyn S V 2010 Cyperus esculentus - a new cultural plant for the USSR: scientific heritage (Voronezh: Scientific book) p 147

6. Yeboah S O, Mitei Y C, Ngila J C et al 2012 Compositional and structural studies of the oils from two edible seeds: Tiger nut, Cyperus esculentum, and asiato, Pachira insignis, from Ghana Food Research International 47 №2 259-266 DOI: https://doi.org/10.1016/j.foodres.2011.06.036.

7. El Shebini S M, Moaty M I A, Tapoza S T et al 2010 Effect of regular consumption of tiger nut (Cyperus esculentus) on insulin resistance and tumor necrosis factor-alpha in obese type2 diabetic Egyptian women Medical Journal Cairo University 78 604-614

8. El Shebini S M, Moaty M I A, Tapoza S T 2011 Short term effect of (Cyperus esculentus) supplement on body weight, insulin sensitivity and serum lipoproteins in Egyptian obese patients International Journal of Academic Research 3 539-544

9. Zharkova I M, Miroshnichenko L A, Klikonos A A 2013 Ground almonds - a promising raw material for the production of flour confectionery products with a functional orientation Economy. Innovations. Quality management № 1(2) 26-30

10. Shevchenko Y P 2015 Sparsely distributed crop - "ground almond" Cyperus esculentus Vegetables of Russia № 1 72-73

11. Zharkova I M, Safonova Y A, Slepokurova Y I 2018 Optimization of processing parameters of ama-ranth grits before grinding into flour Journal of Phys-ics: 
Conference Series (see in books) 1015032156

12. Zharkova I M 2018Research of bio-efficiency of flour from Cyperus esculentus nodules in experiment IN News of higher educational institutions. Food technology № 5-6 (365-366) 109-113

13. Miroshnichenko L A, Kulakova S N, Zharkova I M 2014 Cyperus esculentus innovative perspective raw material for the production of therapeutic and preventive food products in Russia Nutrition issues 83 № S3 189-190

14. Zharkova I M, Samokhvalov A A, Gustinovich V G, Koryachkina S Y, Roslyakov Y F 2019 Review of developments of flour products for gluten-free and gerodietic nutrition Vestnik of Voronezh State University of Engineering Technologies Proceedings of VSUET 81 № 1 213-217

15. Belokurova E V, Kurova M A, Benjko N G 2014 Influence of the Cyperus esculentus processing product on the physical and chemical quality indicators of wheat dough Human health and environmentally friendly food-2014: proceedings of the all-Russian scientific and practical conference (Orel State University - Educational, research and production complex) pp 261-263

16. Bobreneva I V 2019 Possibility of using tiger nuts in meat products Technique and technology of food production 49 № 2 185-19

17. Glotova I A, Grebenshchikov A V, Selezneva N V, Turbina M N 2010 Use of ground almonds in the production of functional products from poultry meat Meat industry № 6 $23-25$ 